\title{
Summary of Estimated Water Use in the United States in 2010
}

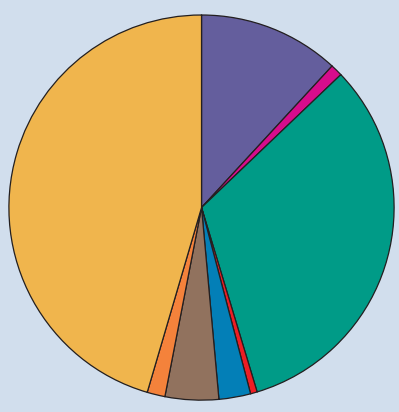

- Total withdrawals were 355,000 million gallons per day (355 billion gallons per day)

- Thermoelectric power, irrigation, and public supply account for 90 percent of the total withdrawals

- Withdrawals declined in all categories except mining and aquaculture

- Freshwater withdrawals were 86 percent of the total, or 306,000 million gallons per day

- Surface water supplied 78 percent of all withdrawals
About 355,000 million gallons per day $(\mathrm{Mgal} / \mathrm{d})$ of water was withdrawn for use in the United States during 2010, a decline of 13 percent from 2005 and a substantial change from the level of about $400,000 \mathrm{Mgal} / \mathrm{d}$ reported from 1985 to 2005 . Withdrawals for 2010 were lower than withdrawals estimated for 1970. Fresh surface-water withdrawals $(230,000 \mathrm{Mgal} / \mathrm{d})$ were almost 15 percent less than in 2005, and fresh groundwater withdrawals $(76,000 \mathrm{Mgal} / \mathrm{d})$ were about 4 percent less than in 2005 . Saline surfacewater withdrawals were $45,000 \mathrm{Mgal} / \mathrm{d}$, or 24 percent less than in 2005 , and saline groundwater withdrawals in 2010, mostly used for mining, were 3,290 Mgal/d.

As in 2005, water withdrawals in four States-California, Texas, Idaho, and Florida - accounted for more than one-quarter of all fresh and saline water withdrawn in the United States in 2010. California accounted for 11 percent of the total withdrawals nationwide and 10 percent of the total freshwater withdrawals. More than 60 percent of California's withdrawals were for irrigation, and 17 percent, almost exclusively saline water, was for thermoelectric power. In Texas, about 45 percent of withdrawals were for thermoelectric power, and 28 percent was for irrigation. Irrigation accounted for 81 percent of water withdrawn in Idaho, and thermoelectric power accounted for 61 percent of water withdrawn in Florida.

\section{Water Use by Category}

During 2010, about 42,000 Mgal/d of freshwater was withdrawn for public supply, which accounted for almost 12 percent of the total water withdrawn. About 63 percent of public-supply withdrawals were from surfacewater sources. Public suppliers deliver water to users for domestic, industrial, commercial, and other purposes. About 57 percent of public-supply withdrawals, or 23,800 Mgal/d, was delivered for domestic use, which includes indoor and outdoor residential uses, such as drinking water, sanitation, and landscape watering. Some residences, especially in rural areas, are not connected to public-supply systems, and water for domestic use is self-supplied from wells or other private sources. Self-supplied domestic withdrawals were about 3,600 Mgal/d during 2010, which provided water to about 44.5 million people, or 14 percent of the U.S. population. More than 98 percent of the water withdrawals for self-supplied domestic use were from groundwater.

Withdrawals for irrigation totaled about $115,000 \mathrm{Mgal} / \mathrm{d}$ and represented 33 percent of total withdrawals and 38 percent of freshwater withdrawals. Irrigation includes water applied by irrigation systems to assist crop and pasture growth or to maintain vegetation in parks and golf courses. Sprinkler and microirrigation systems, more efficient than surface-irrigation methods, were used on about 58 percent of the irrigated acreage nationwide in 2010, and surface water supplied about 57 percent of the total irrigation withdrawals. Of the total irrigation in the United States, 83 percent of withdrawals and 74 percent of the acres irrigated were in the 17 conterminous Western States.
Combined withdrawals for livestock and aquaculture were 3 percent of the total water withdrawals in 2010 . Livestock withdrawals include water for livestock, feedlots, and dairy operations and accounted for 2,000 Mgal/d, most (60 percent) supplied from groundwater. Aquaculture includes fish farms and fish hatcheries and accounted for $9,420 \mathrm{Mgal} / \mathrm{d}$ of freshwater withdrawals, about 81 percent supplied by surface water.

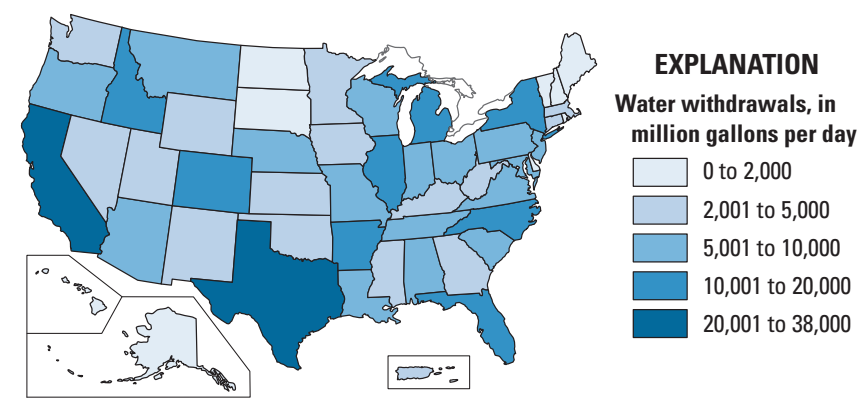

Total water withdrawals by State, 2010.

Self-supplied industrial withdrawal were an estimated 15,900 Mgal/d, about 4 percent of total withdrawals. Industrial water use includes water used in manufacturing and producing commodities such as food, paper, chemicals, refined petroleum, wood products, and primary metals. Although some water for industrial uses was delivered by public suppliers, this amount was not estimated for 2010. Surface water was the source for 82 percent of self-supplied industrial withdrawals, primarily from freshwater sources. About 6 percent of total industrial withdrawals were saline water, primarily from surface-water sources. 
Mining water use includes water used for extracting solid minerals such as copper, liquids such as petroleum, and gases such as natural gas and also includes the injection of water for unconventional oil and gas recovery such as hydraulic fracturing. Withdrawals for mining were estimated to be $5,320 \mathrm{Mgal} / \mathrm{d}$ for 2010 , or about 1 percent of total withdrawals. Groundwater supplied 73 percent of water withdrawn for mining, and 58 percent of mining withdrawals were saline water.

Water for thermoelectric power is used in the process of generating electricity using steam-driven generators. Thermoelectric power accounted for 45 percent of total withdrawals, or 161,000 Mgal/d. Surface water was the source for almost 100 percent of thermoelectric-power withdrawals, and 73 percent of the surface water used was freshwater. Thermoelectric powerplants that use once-through cooling systems accounted for 94 percent of thermoelectricpower withdrawals; recirculating cooling systems made up the remainder. Large volumes of water are needed for cooling in thermoelectric powerplants, which is why facilities typically are located near the coasts, large lakes, or large rivers. About 86 percent of thermoelectric-power withdrawals in 2010 were in Eastern States; many Western States rely on hydroelectric-power generation for much of their power needs.

A bar graph of water withdrawals by major category and State, arranged from west to east, shows the general geographical pattern of water use. Irrigation withdrawals were predominant in many Western States, especially those with only minor thermoelectricpower withdrawals. Generally, thermoelectric power was the largest category of water withdrawal in the Eastern States.

\section{Water Use Trends, 1950-2010} $355,000 \mathrm{Mgal} / \mathrm{d}$ were 13 percent lower than the revised estimate of withdrawals for 2005 of 409,000 Mgal/d. Water withdrawals, estimated at 5 -year intervals since 1950 by the U.S. Geological Survey (USGS), peaked in 1975 and 1980, but then remained fairly stable from 1985 through 2005 before dropping in 2010. Withdrawal estimates in 2010 were substantially lower than 2005 for the largest categories of use. Thermoelectric-power withdrawals declined 20 percent and reflect shifts to cooling systems and generation technologies with lower water requirements, and a new estimation method using linked heat and water budget models for some powerplants. Irrigation withdrawals declined 9 percent as the shift to more water-efficient irrigation systems continued. Although the population served by public supply continued to increase, total public-supply withdrawals declined 5 percent. Self-supplied industrial water use was 12 percent less than in 2005 , continuing a consistent decline since 1985 . Withdrawals also declined for self-supplied domestic use ( 3 percent) and livestock (7 percent). Withdrawals increased for mining (39 percent) and aquaculture (7 percent).
Total withdrawals for 2010 of

\section{Importance of Water-Use Data for the United States}

Every 5 years, the USGS compiles and estimates water-use information in cooperation with State, Federal, and local agencies to document how the Nation's water resources are used. The most recent publication in the series that began in 1950, and the basis of this summary, is USGS Circular 1405, "Estimated use of water in the United States in 2010" (Maupin and others, 2014).

Federal, State, and local agencies have a key role in the collection and dissemination of water-use data. By compiling and publishing water-use estimates for the Nation, the USGS provides water-resource planners with the information needed to address issues related to water-resource allocation and environmental impacts at national, regional, and State levels. Water use also is a key component of the water-budget approach of the National Water Census (http://water.usgs.gov/watercensus/), which supports research focused on improving methods of collection and estimation of water-use data.

\section{Reference}

Maupin, M.A., Kenny, J.F., Hutson, S.S., Lovelace, J.K., Barber, N.L., and Linsey, K.S., 2014, Estimated use of water in the United States in 2010: U.S. Geological Survey Circular 1405, 56 p., http://dx.doi.org/10.3133/cir1405.

\section{By Nancy L. Barber}

\section{For More Information}

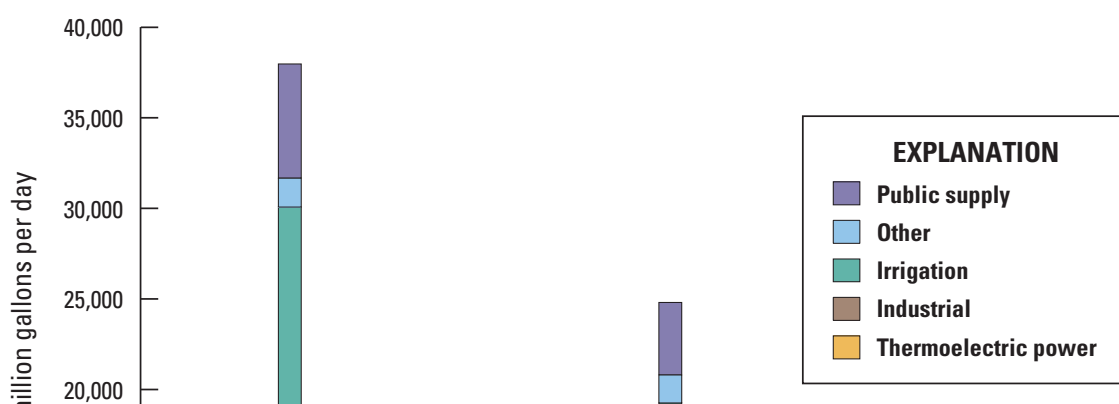

For more information concerning this publication, contact:

USGS National Water-Use Leadership Team wu-info@usgs.gov

Or visit the USGS Water-Use Web site at: http://water.usgs.gov/watuse/

ISSN 2327-6916 (print) ISSN 2327-6932 (online) http://dx.doi.org/10.3133/fs20143109

2010 withdrawals by category, in million gallons per day. States are arranged geographically from west to east. 